\title{
The Influence of Economic Pressures and Gender Roles to Family Resilience During Covid-19 Pandemic
}

\author{
Indah Sukmawati ${ }^{1 *)}$, Herien Puspitawati ${ }^{2}$ \\ ${ }^{1,2}$ Department of Family and Consumer Sciences, Faculty of Human Ecology, IPB University, \\ Bogor 16680, West Java, Indonesia \\ *) Corresponding author: indah_sukma26@apps.ipb.ac.id
}

\begin{abstract}
The existence of Covid-19 has changed the socio-economic life of the community. This study aims to analyze the effect of family characteristics, economic pressure, and gender roles on family resilience during the Covid-19 pandemic. Respondents in this study were wives from intact families with children scattered in Bogor Regency. The design of this research is a crosssectional study with a sampling technique using purposive sampling method with a total sample of 84 families conducted in March 2021. The data processing uses descriptive tests, correlation test, and multiple linear regression tests. The results of the study found that most of the family's economic pressure and gender roles were in the low category. However, most of the family resilience is in the high category. The results of multiple linear regression analysis show that there is a significant negative effect of economic pressure on family resilience. There is a significant positive effect of gender roles on husband's income.
\end{abstract}

Keywords: covid-19, economic pressures, family characteristics, family resilience, gender roles

\begin{abstract}
Abstrak
Keberadaan Covid-19 telah mengubah kehidupan sosial ekonomi masyarakat. Penelitian ini bertujuan untuk menganalisis pengaruh karakteristik keluarga, tekanan ekonomi, dan peran gender terhadap resiliensi keluarga selama masa pandemi Covid-19. Responden dalam penelitian ini adalah istri dari keluarga utuh dengan anak yang tersebar di Kabupaten Bogor. Desain penelitian ini adalah cross-sectional study dengan teknik pengambilan sampel menggunakan metode purposive sampling dengan jumlah sampel sebanyak 84 keluarga yang dilakukan pada bulan Maret 2020. Pengolahan data menggunakan uji deskriptif, uji korelasi, dan uji regresi linier berganda. Hasil penelitian menemukan bahwa sebagian besar tekanan ekonomi keluarga dan peran gender berada pada kategori rendah. Namun, sebagian besar ketahanan keluarga berada pada kategori tinggi. Hasil analisis regresi linier berganda menunjukkan bahwa terdapat pengaruh negatif yang signifikan dari tekanan ekonomi terhadap ketahanan keluarga. Ada pengaruh positif yang signifikan peran gender terhadap pendapatan suami.
\end{abstract}

Kata kunci: covid-19, karakteristik keluarga, ketahanan keluarga, peran gender, tekanan ekonomi 


\section{Introduction}

The current Covid-19 pandemic has changed various aspects of family life. The Covid-19 that is happening around the world is spreading at an alarming speed (Dong, $\mathrm{Du}, \&$ Gardner, 2020). The families directly feel the impact of Covid-19 both in terms of social and economic. In the economic aspect, many families experience a decrease in income, causing economic pressure. The economic pressures is a condition where the family cannot meet their needs properly. Economic difficulties will affect family life, especially through the financial pressures they face (Conger et al., 1992). Yamali and Putri (2020) revealed that during Covid-19 pandemic, there were more than 1.5 million workers were laid off, of which 10 percent were laid off and 90 percent were laid off. International Labor Organization data or ILO (2020) estimates that as many as 1.25 billion workers, representing nearly 38 percent of the global workforce, will be at risk of layoffs. This phenomenon certainly causes problems, because the number of layoffs is getting higher which causes a decrease in family income.

According to the family stress model, difficult conditions such as low incomes and negative economic events (eg job loss) directly impact economic stress in the family (Conger et al., 2002). Families with lower incomes generally experience very severe economic problems (Conger \& Elder, 1994). Economic pressures are generally experienced by people with a low economy, although it is possible that middle-income people can also experience economic pressure. People from different economic backgrounds may be financially well off in one aspect, but less well off in another (Okech et al., 2012). International Labor Organization (ILO, 2020) estimates that 25 million jobs could be lost worldwide as a result of the Covid-19 pandemic. This seriously threatens the survival of family life and family resilience.

Prime, Wade, and Browne (2020) mentioned that the socio-economic changes felt by families due to this pandemic are likely to last a long time. One strategy that can be used in dealing with economic pressures is to increase gender roles in the family. Gender roles are accepted norms associated with the nature of men or women in a particular society (Puspitawati, 2017). Carlson, Petts, and Pepin (2020) found that during the Covid-19 pandemic, the share of household work increased from 26 percent before the pandemic to 42 percent during the pandemic. In going through the difficult times of the Covid-19 pandemic, families are required to be able to survive in carrying out their daily lives by utilizing gender roles partnerships (Kasdi \& Saifudin, 2020). The results of Herawati, Simanjuntak, and Kumalasari (2021) research found that families who apply good gender relations have a good livelihood strategy. Families who have a good livelihood strategy have a low risk of experiencing economic pressure. Reichelt et al. (2021) found that husbands and wives have the same level of unemployment risk, and gender role attitudes may adapt to the realities of life. Uncertain conditions make the family a target from a social and economic perspective, thus requiring cooperation between husband and wife in carrying out family duties (Aswiyanto, 2019).

During this Covid-19 pandemic, husband and wife need to increase gender roles and good cooperation, including in the economic aspect to avoid economic pressures and maintain family resilience. Economic pressure has a significant negative effect on family resilience, if the economic pressure is high, family resilience will be low and the family will become fragile (Herawati, Tyas, \& Trijayanti, 2017). There are families who are able to get through the pressure and some are not successful in the process, this difference is called resilience (Joa" \& Patterson, 2002). Prime, Wade, and Browne 
(2020) stated that family resilience is very much needed during the pandemic in supporting the development and maintenance of families against the situation and building stronger trust to go through events related to Covid-19. Economic pressure can be one of the vulnerability factors in the family. On the other hand, gender roless and good partnerships in the family can keep the family from carrying out its functions properly.

Based on the existing phenomena, this study examines the effect of family characteristics, economic pressure, and gender roles on family resilience. Many previous studies have explained the impact of economic pressure on family resilience, but no one has linked the two with gender role variables. Researchers hypothesize that there is an influence of economic pressure and gender roles on family resilience during the Covid-19 pandemic. Based on the description of the problem above, the objectives of this study is to analyze the influence of family characteristics, economic pressures, and gender roles on family resilience during the Covid-19 pandemic.

\section{Methods}

\section{Participant}

This study used a cross sectional research design. The research was conducted in Bogor Regency which is the area with the highest open unemployment rate in West Java. Data were collected from March to April 2021. The number of samples was 84 people who lived and settled in the same area. The sampling technique of this research is non-probability with voluntary sampling. The data collection is done online. The study population was a complete family consisting of husband, wife, and children and domiciled in Bogor Regency. Research respondents are wives from complete families with at least one child.

\section{Measurement}

The research variables were divided into three groups, namely economic pressure, gender roless, and family resilience. The main concept of economic pressure was developed from the concepts of Elder, Foster, and Conger (1992) and Conger et al. (1992) which divides economic pressure into two, namely objective economic pressure and subjective economic pressure. Family economic pressure is a person's perception of the financial difficulties experienced in meeting family needs based on objective economic pressures and subjective economic pressures. The questionnaire used in this study is the main concept of the dimensions of economic pressure Elder, Foster, and Conger (1992) and Conger et al. (1992) which was then modified by the researcher and produced three indicators of objective economic pressure and five statements for subjective economic pressure. The questionnaire was measured using a Likert scale (14), 1 = never, 2 = sometimes, $3=$ quite often, and $4=$ often with Cronbach's alpha of 0.907 .

The main concept of gender roles used in this study is the concept of Krzaklewska (2014) and Puspitawati (2017). Gender roles are balanced roles between husband and wife and family members in carrying out their roles, functions and duties seen from the partnership and the intensity of their activities in productive, reproductive, and socialcommunity activities. Gender roles variables were measured from a modified questionnaire from Krzaklewska (2014). The Krzaklewska (2014) questionnaire has 10 
statement items, which consist of four reproductive statement items, two productive statement items, and two social-social statement items. After being modified, it produces 10 statement items consisting of four reproductive statement items, three productive statement items, and three social-social statement items. The questionnaire was measured using two dimensional scales, namely the partnership dimension using a Likert scale (1-5), $1=$ husband only, $2=$ wife only, $3=$ husband is dominant, $4=$ wife is dominant, and $5=$ husband and wife are equal, and the dimension of activity intensity using a Likert scale (1-4), $1=$ never, $2=$ sometimes, $3=$ quite often, and $4=$ often with Cronbach's alpha value from both dimension scales of 0.661 .

The main concept of family resilience used in this study is KPPPA (2016). Family resilience is the family's ability to survive and overcome the difficulties faced to meet needs. KPPPA (2016) classifies family resilience into six components, namely legality and family structure, physical resilience, economic resilience, psychological social resilience, socio-cultural resilience, and gender partnerships. This questionnaire has 24 question items. The questionnaire was measured using the Guttman scale (1-2) according to the original text, namely $1=$ yes and $2=$ no with Cronbach's alpha value of 0.676 .

\section{Analysis}

The data obtained is processed through a series of processes in the form of editing, coding, scoring, entry, cleaning, analyzing and interpreting the data. This study uses descriptive analysis and inferential analysis. Descriptive analysis is used to present various descriptions of the variables studied. The variables studied were family characteristics, economic pressure, gender roles, and family resilience using the cut off by Putri, Krisnatuti, and Puspitawati (2019) with categories of $<60$ low, 60-80 moderate, and $>80$ high. Inferential analysis is used to determine the relationship and influence between variables. The data was processed using Microsoft Excel and the Statistical Package for Social Science (SPSS) 25.0 for windows.

\section{Findings}

\section{Husband-Wife Characteristics}

The age of husband and wife is categorized into three groups according to Hurlock (1980), namely early adulthood (18-40 years), middle adulthood (41-60 years), and late adulthood (over 60 years). The results showed that more than half of the husband's age and wife's age were in the early adult category, which was 57.1 percent for husbands with an average age of 39.58 years and 69 percent for wives with an average age of 36.26 years. . The largest proportion of husband and wife education is college graduates (> 12 years). The percentage of the husband's last education is 58.3 percent and the wife is 53.6 percent. This shows that the education that has been undertaken by some husbands and wives has been very good because they have fulfilled the 9-year compulsory education, and even graduated from college. However, there are still education of husbands and wives who did not finish elementary school or did not go to school with husbands amounting to 2.4 percent and wives by 1.2 percent.

Most of the jobs owned by husbands are private employees, which is 40.5 percent. Unlike the case with wives, the proportion of jobs that are mostly owned by wives is other, which is 73.8 percent. Another category of wife's work is housewives. The 
highest proportion of husband's income is in the category of less than IDR 4,217,206, which is 48.8 percent or is below the Bogor Regency UMK. The remaining 51.2 percent is above the Bogor Regency Minimum Wage (UMK). In terms of wife's income, 79.8 percent are also in the category of less than Rp. 4,217,206 or below the Bogor Regency UMK and the remaining 30.2 percent are above the Bogor Regency UMK. Length of marriage ranged from 1 to 36 years with an average length of marriage of 13.08 years.

\section{Family Characteristics}

The number of children is the number of children a husband and wife have. The results showed that the family had at least one child and a maximum of six children. The average number of children owned by a husband and wife is two people. The age of the oldest child owned by the youngest husband and wife is one year old and the age of the oldest child is 34 years old. The average husband and wife have the oldest child aged 11 years. According to the BKKBN (2005), large families can be grouped into three categories, namely small families consisting of 1-4 people, medium families consisting of 5-7 people and large families consisting of 8 or more people. The distribution of family size shows that more than half (73.8\%) of families are in the small family category. It was found that more than half of the respondents $(76.2 \%)$ had savings, and the rest $(23.8 \%)$ had no savings. The highest percentage of savings ownership names is 35.7 percent with husband and wife ownership of savings. The remaining 64.3 percent are those who do not have savings (21.4\%), savings in the name of their husbands $(20.2 \%)$, and savings in the name of their wives $(22.6 \%)$.

\section{Economic Pressures}

Objective economic pressure. The results showed that some respondents (51.2) had greater savings than debt and half of the respondents had a permanent husband's employment status $(50 \%)$. In the ratio of income to expenditure, the results show half of the families whose income is greater than their expenditure $(50 \%)$, then 34.5 percent of families have income that is less than expenditure. This is due to the employment status owned by some respondents is classified as permanent. Overall, the highest proportion of objective economic pressures is in the high category (48.8\%) with the average family objective economic pressure being in the medium category $(63.29 \%)$.

Table 1. Distribution of samples based on economic pressures

\begin{tabular}{lcccccc}
\hline \multirow{2}{*}{ Category } & \multicolumn{2}{c}{$\begin{array}{c}\text { Subjective economic } \\
\text { pressures }\end{array}$} & \multicolumn{2}{c}{$\begin{array}{c}\text { Objective economic } \\
\text { pressures }\end{array}$} & \multicolumn{2}{c}{ Total economic pressures } \\
\cline { 2 - 7 } & $\mathrm{n}$ & $\%$ & $\mathrm{n}$ & $\%$ & $\mathrm{n}$ & $\%$ \\
\hline Low $(<60)$ & 72 & 85.7 & 35 & 41.7 & 75 & 89.3 \\
Moderate $(60-80)$ & 10 & 11.9 & 8 & 9.5 & 8 & 9.5 \\
High $(>80)$ & 2 & 2.4 & 41 & 48.8 & 1 & 1.2 \\
\hline Total & 84 & 100.0 & 84 & 100.0 & 84 & 100.0 \\
Min-max & \multicolumn{2}{c}{$0.0-100.0$} & \multicolumn{2}{c}{$0.0-100.0$} & & $10.0-100.0$ \\
Mean \pm SD & $24.92 \pm 26.06$ & \multicolumn{2}{c}{$63.29 \pm 33.51$} & $44.10 \pm 15.38$ \\
\hline
\end{tabular}

Subjective economic pressure. Based on Table 1, it can be seen that most of the respondents $(85.7 \%)$ have subjective economic pressures which are in the low category. The distribution of respondents' answers shows that some respondents tend to answer never and sometimes. Some respondents feel that their income is sufficient to meet their needs $(51.2 \%)$, have never been in debt $(69 \%)$, and have no difficulty paying bills 
(66.7\%). In total economic pressure, the largest proportion of economic pressure experienced by respondents was in the low category $(89.3 \%)$. This means that most respondents feel that the economic pressure is low or even does not feel the economic pressure at all.

\section{Gender Roles}

Gender partnership. Based on Table 2, almost half of reproductive gender partnerships are in the low category, which is 47.6 percent. In the productive gender partnership, half of the respondents are in the low category, which is 57.1 percent. This means that the gender partnership carried out by husband and wife is still not good in reproductive activities or domestic activities and productive activities that generate money. This is different from the social gender partnership dimension where almost half of the respondents are in the high category, which is 42.9 percent. This means that almost half of the respondents participate quite high in their environment, especially in activities to maintain friendship (89.3\%) and participate in social organizations $(51.2 \%)$.

Table 2. Distribution of samples based on gender partnership dimension

\begin{tabular}{|c|c|c|c|c|c|c|c|c|}
\hline \multirow{2}{*}{ Category } & \multicolumn{2}{|c|}{$\begin{array}{l}\text { Low } \\
(<60)\end{array}$} & \multicolumn{2}{|c|}{$\begin{array}{l}\text { Moderate } \\
(60-80)\end{array}$} & \multicolumn{2}{|c|}{ High $(>80)$} & \multirow{2}{*}{ Min-Max } & \multirow{2}{*}{ Mean \pm SD } \\
\hline & $\mathrm{n}$ & $\%$ & $\mathrm{n}$ & $\%$ & $\mathrm{n}$ & $\%$ & & \\
\hline Reproductive & 40 & 47.6 & 26 & 31 & 18 & 21.4 & $0.0-100.0$ & $58.78 \pm 26.80$ \\
\hline Productive & 48 & 57.1 & 9 & 10,7 & 27 & 32.1 & $0.0-100.0$ & $49.00 \pm 34.84$ \\
\hline Social-community & 32 & 38.1 & 16 & 19 & 36 & 42.9 & $16.67-100.0$ & $67.46 \pm 24.80$ \\
\hline
\end{tabular}

Activity intensity. Based on Table 3, almost half of the respondents in the reproductive dimension are in the high category (45.2\%). However, the largest proportion of productive dimensions $(72.6 \%)$ and social-community $(79.8 \%)$ are in the low category. This means that the intensity of activities carried out by husband and wife in the reproductive aspect or in the domestic area is quite good, but not good in terms of productive and social-society intensity. On the intensity of productive and social activities, more than half of the respondents are in the low category, which is 72.6 percent in productive activities and 79.8 percent in social-social activities with the average also being in the low category. This means that the intensity of activities carried out by husband and wife is still not good in productive activities that make money and more than half of respondents the intensity of activity in participating in their environment is still low. The intensity of husband and wife in participating in activities in the community is still quite low because the category is low.

Table 3. Distribution of samples based on activity intensity dimension

\begin{tabular}{lccccccccc}
\hline \multirow{2}{*}{ Category } & & \multicolumn{2}{c}{$\begin{array}{c}\text { Low } \\
(<60)\end{array}$} & \multicolumn{2}{c}{$\begin{array}{c}\text { Moderate } \\
(60-80)\end{array}$} & $\begin{array}{c}\text { High } \\
(>80)\end{array}$ & Min-Max & Mean \pm SD \\
\cline { 2 - 9 } & & $\mathrm{n}$ & $\%$ & $\mathrm{n}$ & $\%$ & $\mathrm{n}$ & $\%$ & & \\
\hline Reproductive & 24 & 28.6 & 22 & 26.2 & 38 & 45.2 & $25.00-100.0$ & $74.80 \pm 18.34$ \\
Productive & 61 & 72.6 & 20 & 23.8 & 3 & 3.6 & $11.11-100.0$ & $49.60 \pm 18.29$ \\
Social-community & 67 & 79.8 & 16 & 19 & 1 & 1.2 & $11.11-100.0$ & $48.01 \pm 13.81$ \\
\hline
\end{tabular}

Gender roles. Based on Table 4, the largest proportion of gender partnerships is in the low category (48.8\%) with an average gender partnership of 58.42 percent which is also in the low category. The largest proportion of activity intensity is in the low 
category, which is 59.5 percent with an average that is also in the low category $(57.47 \%)$. Overall, gender roless are in the low category with an average of 57.94 percent. This means that husband and wife have not been able to carry out their gender roless well in the family.

Tabel 4. Distribution of samples based on gender roles total

\begin{tabular}{|c|c|c|c|c|c|c|c|c|}
\hline \multirow[t]{2}{*}{ Category } & \multicolumn{2}{|c|}{$\begin{array}{l}\text { Low } \\
(<60)\end{array}$} & \multicolumn{2}{|c|}{$\begin{array}{l}\text { Moderate } \\
(60-80)\end{array}$} & \multicolumn{2}{|c|}{$\begin{array}{l}\text { High } \\
(>80)\end{array}$} & \multirow[t]{2}{*}{ Min-Max } & \multirow[t]{2}{*}{ Mean \pm SD } \\
\hline & $\mathrm{n}$ & $\%$ & $\mathrm{n}$ & $\%$ & $\mathrm{r}$ & $\%$ & & \\
\hline Gender roles & 41 & 48.8 & 30 & 35.7 & 13 & 15.5 & $15.28-95.83$ & $58.42 \pm 20.69$ \\
\hline Activity intensi & 50 & 59.5 & 31 & 36.9 & 3 & 3.6 & $30.56-88.89$ & $57.47 \pm 11.04$ \\
\hline Gender roles total & 47 & 56 & 36 & 42.9 & 1 & 1.2 & $30.56-81.71$ & $57.94 \pm 12.21$ \\
\hline
\end{tabular}

\section{Family Resilience}

Table 5 shows that most of the respondents on the dimensions of legality and structure with the dimensions of social psychological resilience are in the high category, namely 90.5 percent and 96.4 percent, respectively. The average on the dimensions of legality and structure is 96.03 points, while psychological social resilience is 98.01. More than half of the respondents in the dimensions of physical resilience, dimensions of economic resilience, and dimensions of gender partnership are also in the high category, namely 75 percent, 69 percent, and 65.5 percent. The averages on the dimensions of physical resilience, economic resilience, and gender partnership were 92.86 points, 85.2 points, and 87.50 points. In the socio-cultural dimension, 46.4 percent are in the high category and 42.9 percent are in the medium category with an average of 76.98 points which is the lowest average compared to other dimensions.

Table 5. Distribution of samples based on total family resilience

\begin{tabular}{|c|c|c|c|c|c|c|c|c|}
\hline \multirow{2}{*}{ Category } & \multicolumn{2}{|c|}{$\begin{array}{l}\text { Low } \\
(<60)\end{array}$} & \multicolumn{2}{|c|}{$\begin{array}{c}\text { Moderate (60- } \\
80)\end{array}$} & \multicolumn{2}{|c|}{$\begin{array}{l}\text { High } \\
(>80)\end{array}$} & \multirow{2}{*}{ Min-Max } & \multirow{2}{*}{ Min-Max } \\
\hline & $\mathrm{n}$ & $\%$ & $\mathrm{n}$ & $\%$ & $\mathrm{n}$ & $\%$ & & \\
\hline Legal \& Structure & 1 & 1.2 & 7 & 8.3 & 76 & 90.5 & $0.0-100.0$ & $96.03 \pm 14.08$ \\
\hline Physical resilience & 3 & 3.6 & 18 & 21.4 & 63 & 75 & $50.0-100.0$ & $92.86 \pm 13.20$ \\
\hline Economic resilience & 9 & 10.7 & 17 & 20.2 & 58 & 69 & $14.29-100.0$ & $85.20 \pm 17.24$ \\
\hline $\begin{array}{l}\text { Psychological social } \\
\text { resilience }\end{array}$ & 1 & 1.2 & 2 & 2.4 & 81 & 96.4 & $0.0-100.0$ & $98.01 \pm 11.97$ \\
\hline $\begin{array}{l}\text { Socio-cultural } \\
\text { resilience }\end{array}$ & 9 & 10.7 & 36 & 42.9 & 39 & 46.4 & $0.0-100.0$ & $76.98 \pm 26.37$ \\
\hline Gender partnership & 9 & 10.7 & 20 & 23.8 & 55 & 65.5 & $25.0-100.0$ & $87.50 \pm 20.35$ \\
\hline
\end{tabular}

Table 6. Distribution of samples based on total family resilience

\begin{tabular}{lcc}
\hline \multirow{2}{*}{ Category } & \multicolumn{2}{c}{ Total family resilience } \\
\cline { 2 - 3 } & $\mathrm{n}$ & $\%$ \\
\hline Low $(<60)$ & 3 & 3.6 \\
Moderate $(60-80)$ & 9 & 10.7 \\
High $(>80)$ & 72 & 85.7 \\
\hline Total & 84 & 100.0 \\
Min-max & \multicolumn{2}{c}{$45.8-100.0$} \\
Mean \pm SD & \multicolumn{2}{c}{$89.43 \pm 9.94$} \\
\hline
\end{tabular}

Table 6 presents the distribution of respondents based on total family resilience. The results show that most of the respondents are in the high category, which is 83.3 percent. The average value of total family resilience is 88.79 . This shows that the 
resilience of the respondent's family is quite good and the family can survive and adapt to difficult conditions.

\section{The Effect of Family Characteristic, Economic Pressures, and Gender Roles on Family Reslience}

The results of the multiple linear regression test for total family resilience below have previously met the classical assumption test. Table 7 presents the results of Adjusted $\mathrm{R}^{2}$ of 0.241 . This shows that as much as 24.1 percent of family resilience is influenced by husband's income, total economic pressure, and gender roless. Meanwhile, the remaining 75.9 percent is influenced by other variables outside the study.

Based on Table 7 , economic pressure $(\beta=-0.173 ; p=0.084)$ has a significant negative effect on family resilience. This means that for every one unit increase in economic pressure faced, it will reduce family resilience by 0.173 points. The results also showed that husband's income $(\beta=0.274 ; p=0.019)$, and gender roles $(\beta=0.297$; $\mathrm{p}=0.008$ ) had a significant positive effect on family resilience. That is, every increase in one unit of husband's income and gender roles will increase family resilience by 0.274 ; 0.297 points. Based on this, the higher the family's economic pressure, the lower the family's resilience. However, if the husband's income is high and the gender roles performed by husband and wife are high, the family's resilience will be better.

Table 7. Regression coefficient

\begin{tabular}{|c|c|c|c|}
\hline \multirow[t]{2}{*}{ Variabel } & \multicolumn{3}{|c|}{ Total family resilience } \\
\hline & B unstandardize & B Standardize & Sig. \\
\hline Constanta & 74.82 & & 0.000 \\
\hline Husband's age & -0.104 & -0.132 & 0.267 \\
\hline Husband's education & 0.081 & 0.009 & 0.950 \\
\hline Wife's education & 1.978 & 0.231 & 0.137 \\
\hline Husband's income & 1.644 & 0.274 & $0.019 * *$ \\
\hline Wife's income & -1.271 & -0.162 & 0.136 \\
\hline Number of children & 0.934 & 0.103 & 0.376 \\
\hline Economic pressures & -0.099 & -0.173 & $0.084 *$ \\
\hline Gender roles & 0.198 & 0.297 & $0.008 * *$ \\
\hline Adjusted R-square & \multicolumn{3}{|c|}{0.241} \\
\hline $\mathrm{F}$ & \multicolumn{3}{|c|}{4.210} \\
\hline Sig & \multicolumn{3}{|c|}{0.000} \\
\hline Df & \multicolumn{3}{|c|}{8} \\
\hline $\mathrm{n}$ & \multicolumn{3}{|c|}{82} \\
\hline
\end{tabular}

\section{Discussion}

This study uses a structural functional theory and gender theory approach through economic pressure, gender roless, and family resilience. The emphasis of functional structural theory lies on a unity, if there is a change in the structure of the organism it will affect changes in the social environment (Megawangi, 2014). The structuralfunctional theory approach also emphasizes the balance of a stable system in the family and the stability of the social system in society (Puspitawati, 2017). Gender theory in this study is used to better understand the gender roles of husband and wife. Gender can be interpreted as the difference in roles between men and women in society which is manifested in the structure, relationships, and culture in behavior (Riley, 1997). 
Family characteristics in this study are the age of husband and wife, husband and wife education level, husband and wife income, length of marriage, number of children, and family size. The age of the husband and the age of the wife are categorized based on age grouping according to Hurlock (1980). The results showed that most of the husband and wife were in early adulthood with the majority having a fairly good level of education, namely graduating from college. What is quite interesting is that some of the husband's income is above the UMK in Bogor Regency and most of the wives have income below the UMK because they work as housewives. The average length of marriage is 13.08 years and the average number of children is two. Most of the respondents belong to a small family consisting of approximately four people in the family.

Economic pressures are constructs that reflect painful realities created by difficult conditions, such as not being able to buy necessary goods and services, having to save on daily expenses due to limited resources, and not being able to pay monthly bills (Conger et al., 2002). Elder et al. (1992) defines economic stress as the financial pressure that families face in the midst of economic hardship. The family economic pressure in the results of this study was in the low category, both objective and subjective economic pressure, meaning that the family almost did not experience economic difficulties. The family is able to meet the needs of daily life, does not lack money at the end of the month, and is able to pay water and electricity bills because they have a fairly good income. Prawitz et al. (2013) mentioned that economic pressures were the result of economic hardship and low incomes. This means that families with high incomes tend to avoid economic pressures. This is one of the factors that causes the economic pressure faced by the family to be quite low. Lower income is a predictor of economic hardship, but families with good incomes will avoid economic pressures (Gudmunson et al., 2010). Couples who have low incomes are more likely to experience financial disputes and increase tension in the family, conversely if the spouses have high incomes it will reduce tension in the family. (Masarik et al., 2016; Schieman \& Young, 2011). Families need to be frugal and make financial adjustments to prevent economic stress (Ranta et al., 2020).

Gender roles are accepted norms related to the nature of men or women in a particular society (Puspitawati, 2017). The results showed that the average gender roles of husband and wife were in the low category. This means that the role of gender in the family during the pandemic is still not good. Gender roles have two dimensions, namely the intensity of activities and partnerships in which there are three sub-dimensions consisting of reproductive, productive, and social-social sub-dimensions. The results of the study show that the reproductive/domestic activity sub-dimension is in the low category where the wife's role is more dominant, while in the productive or public role sub-dimension, the husband has a more dominant role. However, in the socio-societal sub-dimension, the gender roles of husband and wife tend to be equal. In this pandemic situation, Carlson, Petts, and Pepin (2020) found that there was an increase in time at home due to unemployment, reduced working hours or other underlying changes in the division of responsibilities within the household. Oktariyanto et al. (2020) and Asriani (2021) also mentioned that the wife is the center of the family, and the role of the wife in domestic activities has increased during the pandemic. Ericksen, Yancey, and Ericksen (1979) explained that the husband's best help in the household is his success as a provider. High-income husbands are much less likely to do housework and childcare than low-income or unemployed husbands (Fodor et al., 2021; Solaz, 2005). During a 
pandemic, although social-community activities have reduced in intensity, communication can still be established well through digital media. Harini et al. (2020) explained that during the Covid-19 pandemic, families had more time with family and built good communication, even through communication media. Rizkillah, Krisnatuti, \& Herawati (2021) also explained that in the pandemic Covid-19 almost half husband and wife have high category of love and directing dimension in husband-wife interaction.

The relationship of gender roless in the family will determine the responsibilities of each party (Avotri \& Walters, 2001). Men and women contribute to their household livelihoods in different ways, and have different gender obligations to fulfill (Kiewisch, 2015). Women who have independent income will support the family economy and have greater authority in the family so they can avoid vulnerability (Orloff, 1993). Families need to have a balanced role in every dimension. Incompatibility of gender roless in the family will lead to violations of the "norms" of these roles (Hu et al., 2021). Empowerment of women in the household is important to do to increase the allocation of resources so that family resilience is getting better (Kiewisch, 2015). Gender roless and relationships affect the productive activities a person can undertake, his or her access to the resources needed for those activities, and the freedom to manage income from livelihood activities. (Kiewisch, 2015).

Family resilience is a strength both in terms of input, process, and output outcomes and coping strategies in adapting to the environment whose impact is felt by the family (Puspitawati, 2017). KPPPA (2016) divides family resilience into six dimensions, namely the dimensions of legality and structure, physical resilience, economic resilience, psychological social resilience, socio-cultural resilience, and gender partnerships. The results showed that total family resilience was in the high category. This can be seen from the dimensions of legality and structure and the dimensions of psychological social resilience, which are mostly in the high category as well. Walsh (2016) explained that family resilience is formed through an interactive and synergistic process through mutual communication, sharing emotions, and solving problems together. A balance of process components is also necessary for adaptation to emerging challenges (Walsh, 2016). Family resilience will form resilience and give the family the ability to bounce back after facing stressful situations and will return to their function before the condition (Hawley \& Dehaan, 1996). The overall effective functioning of the family system tends to strengthen the resilience of other family members in the face of adversity (Walsh, 2016). Close relationships in the family can overcome unfavorable circumstances in the family, especially during the Covid-19 pandemic. Routines and rituals carried out in the family can also increase family resilience (Harrist et al., 2019). The level of family religiosity has a significant positive effect on the subjective welfare of the family (Wati \& Rizkillah, 2021).

The results of multiple linear regression show that the higher the economic pressure faced by the family, the lower the family's resilience. Family resilience is the family's ability to manage resources and overcome problems faced in order to meet the physical and psychosocial needs of the family. The results of this study support previous research which shows that economic pressure has a significant negative effect on family resilience (Conger, Rueter, \& Elder, 1999; Herawati, Tyas, \& Trijayanti, 2017). One of the economic pressures is marked by the ratio between income and expenditure (Elder, Foster, \& Conger, 1992). During the Covid-19 pandemic, many families lost their jobs, especially in jobs in the informal sector (PH et al., 2020). Sudden job loss leads to reduced income to survive (Peterman et al., 2020). In addition, 
the results showed that husband's income had a significant positive effect on family resilience. That is, husbands who have relatively high incomes will have good family resilience. This is in line with research (Sunarti \& Fitriani, 2010; Herawati, Pranadji, \& Rukmayanti, 2012) that family resilience will increase if income increases.

In the regression test, it was also found that gender roles had a significant positive effect on family resilience. This is in line with the research results BKKBN (2020) who found that the division of husband and wife gender roles during the Covid-19 pandemic was quite good, including in maintaining good relations with their families and the environment where they lived. Czymara, Langenkamp, and Cano (2021) also explained that during the Covid-19 pandemic, the division of labor in the family between productive and reproductive follows the traditional male breadwinner model which strengthens family resilience. Rosenfeld and Tomiyama (2021) also found that gender roless performed during the pandemic were better so that families became better able to adapt to the environment. However, the results of another study found that during the Covid-19 pandemic, the allocation of gender roles was carried out by husband and wife focusing on each aspect (Andrew et al., 2020). The wife is more involved in reproductive and parenting activities, while the husband is more focused on productive activities to earn a living.

Family economic pressures need to be overcome and gender roles need to be improved to build family resilience. It is important to encourage cooperation between husband and wife to result in joint decision making in the household (Kiewisch, 2015). Therefore, functional structural theory that directs families to live in harmony and harmony with their social environment is important to do.

The limitation of this research is that the research was only conducted in one area, namely Bogor Regency, so that the scope of this research is not wide enough. The data collection technique used in this study is also limited to non-probability voluntary sampling because it is not possible to go directly to the field so that data collection is done online. Data retrieval done online has an effect on the target respondents, because researchers can only get answers from only one source, cannot get both results, namely from husband and wife. In addition, researchers are also unable to conduct in-depth interviews or in-depth interviews with respondents to explore further.

\section{Conclusion and Recommendation}

\section{Conclusion}

Families are in early adulthood which is a productive age so they have better potential in economic activities. Most of the husband and wife's last education is high (college graduate). The average income of husband and wife is mostly below the UMK in Bogor Regency. The average length of marriage is 13.08 years with the average number of children owned is two people and the average family size is in the small family category $(\leq 4$ people).

The results showed that economic pressure had a significant negative effect on family resilience and gender roles had a significant positive effect on family resilience. That is, the lower the economic pressure and the higher the gender roles of husband and wife, the better the family resilience. 


\section{Recommendation}

Based on the results of the study, families and communities are expected to be able to maintain the family economy by being frugal and using money wisely so that economic pressure does not increase. Families and communities also need to increase gender roles, especially in the productive and social dimensions of society. The way that can be done to increase gender roles is in the productive dimension by doing equal side work between husband and wife to meet family needs. In addition, families also need to seek information for additional income during the Covid-19 pandemic together and compactly so that gender roles in the family will be better and at the same time overcome the economic pressures they face. Family resilience in the socio-cultural dimension also needs to be improved by paying more attention to elderly family members, being more active in community activities, and praying regularly. For the government, it is expected to increase programs related to gender roles in the family so that the role of husband and wife is getting better and avoiding conflicts in the family. Family empowerment programs that involve community participation are also expected to increase socio-cultural resilience. For future researchers, it is possible to examine the factors that cause low gender roles in the family based on single earners and dual earners.

\section{References}

[BKKBN] Badan Kependudukan dan Keluarga Berencana Nasional. (2020). Survei kondisi keluarga pada masa pandemi covid-19. In Bkkbn.

[ILO] International Labour Organization. (2020). Pemantauan ILO edisi ke-2: covid-19 dan dunia kerja. https://gisanddata.maps.arcgis.com/apps/opsdashboard/index.html\#/

[KPPPA] Kementrian Pemberdayaan Perempuan dan Perlindungan Anak. (2016). Pembangunan ketahanan keluarga.

Andrew, A., Cattan, S., Costa Dias, M., Farquharson, C., Kraftman, L., Krutikova, S., Phimister, A., \& Sevilla, A. (2020). The gendered division of paid and domestic work under lockdown. IZA Discussion Paper, 13500.

Asriani, D. D. (2021). The changes in the daily activities cycle of women informal workers during the covid-19 pandemic: Vulnerability and resilience. Jurnal Studi Gender, 16(1), 19-42. Doi: https://doi.org/10.21580/sa.v16i1.7112

Aswiyanto, A. (2019). Women, reconciliation right and gender justice in islam family law. Jurnal Penelitian, 173. Doi: https://doi.org/10.28918/jupe.v16i2.2292

Avotri, J. Y., \& Walters, V. (2001). "We women worry a lot about our husbands": Ghanaian women talking about their health and their relationships with men. Journal of Gender Studies, 10(2), 197-211. Doi: https://doi.org/10.1080/09589230120053319

Carlson, D., Petts, R., \& Pepin, J. (2020). Changes in parents' domestic labor during the covid-19 pandemic. Doi: https://doi.org/10.31235/osf.io/jy8fn

Conger, R. D., Conger, K. J., Elder, G. H., Jr, Lorenz, F. O., Simons, R. L., \& Whitbeck, L. B. (1992). A family process model of economic hardship and adjustment of early adolescent boys. Child development, 63(3), 526-541. Doi: https://doi.org/10.1111/j.1467-8624.1992.tb01644.x

Conger, R. D., \& Elder, G. H. (1994). Families in troubles times: Adapting to change in 
rural America. Aldine de Gruyter.

Conger, R. D., Rueter, M. A., \& Elder, G. H. (1999). Couple resilience to economic pressure. Journal of Personality and Social Psychology, 76(1), 54-71. Doi: https://doi.org/10.1037/0022-3514.76.1.54

Conger, R. D., Wallace, L. E., Sun, Y., Simons, R. L., McLoyd, V. C., \& Brody, G. H. (2002). Economic pressure in african american families: a replication and extension of the family stress model. Developmental Psychology, 38(2), 179-193. Doi: https://doi.org/10.1037/0012-1649.38.2.179

Czymara, C. S., Langenkamp, A., \& Cano, T. (2021). Cause for concerns: gender inequality in experiencing the COVID-19 lockdown in Germany. European Societies, 23(S1), S68-S81. Doi: https://doi.org/10.1080/14616696.2020.1808692

Dong, E., Du, H., \& Gardner, L. (2020). An interactive web-based dashboard to track COVID-19 in real time. In The Lancet Infectious Diseases (Vol. 20, Issue 5, pp. 533-534). Lancet Publishing Group. Doi: https://doi.org/10.1016/S14733099(20)30120-1

Elder, G. H., Foster, E. M., \& Conger, R. D. (1992). Families under economic pressure. Journal of Family Issue, 13(1), 5-37. Doi: https://doi.org/10.1177/019251392013001002

Ericksen, J. A., Yancey, W. L., \& Ericksen, E. P. (1979). The division of family roles. Journal of Marriage and the Family, 41(2), 301-313. Doi: https://doi.org/10.2307/351698

Fodor, É., Gregor, A., Koltai, J., \& Kováts, E. (2021). The impact of COVID-19 on the gender division of childcare work in Hungary. European Societies, 23(S1), S95S110. Doi: https://doi.org/10.1080/14616696.2020.1817522

Gudmunson, C. G., Son, S., Lee, J., \& Bauer, J. W. (2010). EITC participation and association with financial distress among rural low-income families. Family Relations, 59(4), 369-382. Doi: https://doi.org/10.1111/j.1741-3729.2010.00609.x

Harini, S., Suhita, D., \& Itasari, A. A. (2020). The role of women in improving family resilience in the middle of the covid-19 pandemic. SALASIKA: Indonesian Journal of Gender, Women, Child, and Social Inclusion's Studies, 3(2), 91-102. Doi: https://doi.org/10.36625/sj.v3i2.70

Harrist, A. W., Henry, C. S., Liu, C., \& Morris, A. S. (2019). Family resilience: The power of rituals and routines in family adaptive systems. American Psychological Association. Doi: https://doi.org/10.1037/0000099-013

Hawley, D. R., \& Dehaan, L. (1996). Toward a definition of family resilience: integrating life-span and family perspectives. Family Process, 35(3), 283-298. Doi: https://doi.org/10.1111/j.1545-5300.1996.00283.x

Herawati, T., Tyas, F. P. S., \& Trijayanti, L. (2017). Tekanan ekonomi, strategi koping, dan ketahanan keluarga yang menikah usia muda. Jurnal Ilmu Keluarga Dan Konsumen, 10(3), 181-191. Doi: https://doi.org/10.24156/jikk.2017.10.3.181

Herawati, T., Pranadji, D. K., \& Rukmayanti, I. Y. (2012). Dukungan sosial dan ketahanan keluarga peserta dan bukan peserta program nasional pemberdayaan masyarakat (PNPM) mandiri. Jurnal Ilmu Keluarga dan Konsumen, 5(1), 1-10. Doi: https://doi.org/10.24156/jikk.2012.5.1.1

Herawati, Tin, Simanjuntak, M., \& Kumalasari, B. (2021). Investigating the quality of life on farmer family: roles of gender relations, economic pressure, financial management, and livelihood strategies. Journal of Family Sciences, 6(1), 37-52. Doi: https://doi.org/10.29244/jfs.v6i1.35796 
Hu, Y., Li, J., Ye, M., \& Wang, H. (2021). The relationship between couples' genderrole attitudes congruence and wives' family interference with work. Psychology Research and Behavior Management, 14, 49-59. Doi: https://doi.org/10.2147/PRBM.S286119

Hurlock, E. (1980). Psikologi Perkembangan. Erlangga.

ILO. (2020). COVID-19 dan dunia kerja: Dampak dan tanggapan.

Joa“, J., \& Patterson, J.M. (2002), integrating family resilience and family stress theory. Journal of Marriage and Family, 64, 349-360. Doi: https://doi.org/10.1111/j.1741-3737.2002.00349.x.

Kasdi, A., \& Saifudin. (2020). Resilience of muslim families in the pandemic era: indonesian. Jurnal Penelitian, 17(1), 81-94. Doi: https://doi.org/10.1016/j.obmed.2020.100282

Kiewisch, E. (2015). Looking within the household: A study on gender, food security, and resilience in cocoa-growing communities. Gender and Development, 23(3), 497-513. Doi: https://doi.org/10.1080/13552074.2015.1095550

Krzaklewska, E. (2014). Working paper No . 1 . 2 " gender equality and quality of life state of art report " measurement of gender equality - analysing dimensions , embracing areas, considering contexts. 1, 1-33.

Masarik, A. S., Martin, M. J., Ferrer, E., Lorenz, F. O., Conger, K. J., \& Conger, R. D. (2016). Couple resilience to economic pressure over time and across generations. Journal of Marriage and Family, 78(2), 326-345. Doi: https://doi.org/10.1111/jomf.12284

Megawangi, R. (2014). Membiarkan berbeda: sudut pandang baru tentang relasi gender (1st ed.). Indonesia Heritage Foundation.

Okech, D., Howard, W. J., Mauldin, T., Mimura, Y., \& Kim, J. (2012). The effects of economic pressure on the resilience and strengths of individuals living in extreme poverty. Journal of Poverty, 16(4), 429-446. Doi: https://doi.org/10.1080/10875549.2012.720659

Oktriyanto, Amrullah, H., Pujihasvuty, R., Nasution, S. L., Puspitasari, M. D., Puspitawati, H., \& Herawati, T. (2020). The impact of covid-19 on elderly care: What's next? Family Situation at the Early of Covid-19 Pandemic in Indonesia, $108-199$.

Orloff, A. S. (1993). Gender and the social rights of citizenship: the comparative analysis of gender relations and welfare states. American Sociological Review, 58(3), 303-328. Doi: https://doi.org/10.2307/2095903

Peterman, A., Potts, A., O’Donnel, M., Thompson, K., Shah, N., Oertelt-Prigione, S., \& Gelder, N. van. (2020). Pandemics and violence against women and children. American Journal of Criminal Justice, April 2020. Doi: https://doi.org/10.1007/s12103-020-09578-6

PH, L., Suwoso, R. H., Febrianto, T., Kushindarto, D., \& Aziz, F. (2020). Dampak pandemi covid-19 bagi perekonomian masyarakat desa. Indonesian Journal of Nursing and Health Sciences, 1(1), 37-48.

Prawitz, A. D., Kalkowski, J. C., \& Cohart, J. (2013). Responses to economic pressure by low-income families: Financial distress and hopefulness. Journal of Family and Economic Issues, 34(1), 29-40. Doi: https://doi.org/10.1007/s10834-0129288-1

Prime, H., Wade, M., \& Browne, D. T. (2020). Risk and resilience in family well-being during the covid-19 pandemic. American Psychologist, 75(5), 631-643. Doi: 
https://doi.org/10.1037/amp0000660

Puspitawati, H. (2017). Gender dan keluarga: konsep dan realita di indonesia (Revisi). IPB Press.

Putri, D. K., Krisnatuti, D., \& Puspitawati, H. (2019). Kualitas hidup manusia: Kaitannya dengan integritas diri, interaksi suami-istri, dan fungsi keluarga. Jurnal Ilmu Keluarga Dan Konsumen, 12(3), 181-193.

Ranta, M., Punamäki, R. L., Chow, A., \& Salmela-Aro, K. (2020). The economic stress model in emerging adulthood: The role of social relationships and financial capability. Emerging Adulthood, 8(6), 496-508. Doi: https://doi.org/10.1177/2167696819893574

Riley N. E. (1997). Gender, power, and population change. Population bulletin, 52(1), 21-48.

Rizkillah, R., Krisnatuti, D., \& Herawati, T. (2021). The Correlation between Family Characteristics and Husband and Wife Interaction during the Covid-19 Pandemic. Journal of Family Sciences, 6(1), 53-66. Doi: https://doi.org/10.29244/jfs.v6i1.35587

Rosenfeld, D. L., \& Tomiyama, A. J. (2021). Can a pandemic make people more socially conservative? Political ideology, gender roles, and the case of COVID-19. Journal of Applied Social Psychology, 51(4), 425-433. https://doi.org/10.1111/jasp.12745

Schieman, S., \& Young, M. (2011). Economic hardship and family-to-work conflict: the importance of gender and work conditions. Journal of Family and Economic Issues, 32(1), 46-61. Doi: https://doi.org/10.1007/s10834-010-9206-3

Solaz, A. (2005). Division of domestic work: Is there adjustment between partners when one is unemployed?: Evidence from french couples. Review of Economics of the Household, 3(4), 387-413. Doi: https://doi.org/10.1007/s11150-005-4941-1

Sunarti, E., \& Fitriani, F. (2010). Kajian modal sosial, dukungan sosial, dan ketahanan keluarga nelayan di daerah rawan bencana. In Jurnal Ilmu Keluarga dan Konsumen, 3(2), 93-100. Doi: https://doi.org/10.24156/jikk.2010.3.2.93

Walsh, F. (2016). Family resilience: a developmental systems framework. European Journal of Developmental Psychology, 13(3), 313-324. Doi: https://doi.org/10.1080/17405629.2016.1154035

Wati, R., A. \& Rizkillah, R. (2021). Pengaruh religiusitas terhadap kesejahteraan subjektif pada keluarga ibu bekerja informal selama pandemi covid-19. JKKP (Jurnal Kesejahteraan Keluarga dan Pendidikan), 8(02), 164-174. Doi: https://doi.org/10.21009/JKKP.082.05

Yamali, F. R., \& Putri, R. N. (2020). Dampak pandemi covid-19 terhadap ekonomi indonesia. Journal of Economics and Bussiness, 4(2), 384-388. Doi: https://doi.org/10.33087/ekonomis.v4i2.179 